ToSEE - Tourism in Southern and Eastern Europe, Vol. 6, pp. 709-723, 2021.

\title{
THE CONCEPT OF SHADOW DESTINATION \& VALUE CREATION
}

\section{Anna Sörensson Ulrich Schmudde}

https://doi.org//10.20867/tosee.06.47

\begin{abstract}
Purpose - The purpose of this paper is to gain a deeper understanding of the concept of shadow destinations. What added value do shadow destinations create for the main attraction in a region? How can a shadow destination create a value of its own?

Methodology - The study was constructed as a qualitative multiple-case study. Five different shadow destinations in Sweden were selected based on stratified selection. Sweden was divided into five regions, and one destination from each region was identified. Data were collected through interviews, observations and written materials during 2019-2020.

Findings - The findings show that shadow destinations are highly dependent on some sort of main attraction in the region. The results also show that there exist different types of relationships between the shadow destinations and the main attractions. The results also show that shadow destinations can create value for tourists in order to become more important for tourism in the region, as well as to become main destinations by themselves.

Contribution - The theoretical contribution from this study shows that the concept of shadow destinations has not been addressed to any great extent in tourism research and that this concept requires further studies. This study makes a contribution to tourism development of shadow destinations.
\end{abstract}

Keywords: destination, shadow destination, tourism development, value, value creation.

\section{INTRODUCTION}

The research field of destinations is an important one, and studies have included several different perspectives (Volgger et al. 2021). Areas like destination management (Laws 1995; Ritchie and Crouch 2003), destination governance (Laesser and Beritelli 2013; Pechlaner et al. 2010) and destination leadership (Beritelli and Bieger 2014; Pechlaner et al. 2014) have contributed to research and practice regarding tourism destinations (Volgger et al. 2021). Volgger et al. (2021) argue that it took considerable theorising on established tourism destinations for them to be considered as a worthy area of study and also as relevant competitive units in the tourism system. Researchers have for decades focused on issues concerning tourism development (Shen et al. 2018; Saarinen et al. 2017). The issue of tourism development of a place - a country or smaller area - is a complex matter (Kladou et al. 2017). Tourists travel to different places and destinations and, from their perspective, that particular place is the "destination". For well-established destinations, which tourists clearly see as such, the task is easy, but there might be places that exist close to a well-established destination, and these places are not as clear in the mind of the tourist. These areas, places or parts adjacent to a destination could be 
ToSEE - Tourism in Southern and Eastern Europe, Vol. 6, pp. 709-723, 2021. A. Sörensson, U. Schmudde: THE CONCEPT OF SHADOW DESTINATION \& VALUE CREATION

consider as shadow destinations (Brambini and Vang 2013; Schmudde and Sörensson 2020).

Researchers have largely not addressed the issue of shadow destinations. The first to do so were Hudman and Jackson (2003), who argued that places that are situated near popular attractions are affected by the shadow effect:

"The shadow effect refers to destinations that are near other major destinations. The concept comes from a geographic term "rain shadow". Some localities get less rain because the precipitation is diverted by mountains or wind patterns. Thus, one destination may be in the shadow of another destination, which is the preferred destination. Because they are close to the preferred destination, tourists will also visit the shadow destinations, but stay less time" (Hudman and Jackson 2003, 31).

Shadow destinations are therefore of great interest to study further. Tourists come to a place or a destination and might be interested in more experiences then just the main attraction. Tourists often see the place or destinations as one unit, but in reality, it is a complex network that consists of many different stakeholders with different roles to play in creating value for the tourists (Haugland et al. 2011). It might be hard to determine what is a destination from a geographical perceptive. Where does a destination start and finish, particularly in the mind of the tourist?

The issue of considering the destination as a unit has resulted in a large amount of research focusing on issues related to destination development (Haugland et al., 2011). This research might influence places and destinations that are situated close to wellknown destinations that have a strong brand. Ashton $(2014,279)$ argues that "brand is considered as a powerful instrument in creating a successful destination".

Destinations that have a strong brand often also have a strong identity and image. Tourists feel recognition and therefore enjoy the feeling of familiarity. Shadow destinations could therefore create relationships with famous destinations close to their area and benefit from their branding. This article defines shadow destinations as destinations that exist in the shadow of a well-established destination that has a strong and well-known brand. These well-established destinations with famous brands and strong identities attract many tourists, while shadow destinations are home to struggling tourism businesses and often experience insufficient tourism development.

Exploring shadow destinations can enable a deeper understanding of the concept. Furthermore, it is valid to investigate how shadow destinations can contribute to increased value of an established destination. Value creation is a well-established research field (Vargo and Lusch 2004), but the term has not previously been used in relation to shadow destinations. Value creation (based on the Service-Dominant Logic, also known as the S-D logic) has become the driving paradigm in value co-creation research (Vargo and Lusch 2016; 2004; Payne et al. 2008). This paradigm argues that customers (e.g., tourists) must play an active part in co-creating experiences and value with the destination (Chathoth et al. 2016; Heo 2016; Johnson and Neuhofer 2017; Vargo et al. 2008; Vargo and Lusch 2004). 
ToSEE - Tourism in Southern and Eastern Europe, Vol. 6, pp. 709-723, 2021.

A. Sörensson, U. Schmudde: THE CONCEPT OF SHADOW DESTINATION \& VALUE CREATION

The purpose of this paper is to gain a deeper understanding of the relationship between shadow destinations and value creation. What value do shadow destinations create for the main attraction in a region? How can a shadow destination create a higher value of its own?

\section{SHADOW DESTINATIONS AND VALUE CREATION}

\subsection{Destination and the Concept of the Shadow Destination}

There is a great deal of research on what a destination is as well as on destination development (Saraniemi and Komppula 2019; Tinsley and Lynch 2001). The concept of the shadow destination has however not yet attracted widespread interest, despite the existence of many such destinations around the globe (Brambini and Vang 2013; Hudman and Jackson 2003; Schmudde and Sörensson 2020). There is therefore an important need for more research. Destination development and destinations (e.g., shadow destinations) can however be divided into sub-categories and viewed from different perspectives (Tinsley and Lynch 2001). Lew and McKercher (2002) argue that a destination or a place, depending on its characteristics, can be one of five different types: (1) Single Destination, (2) Gateway Destination, (3) Egress Destination, (4) Touring Destination or (5) Hub Destination. The Single Destination pattern involves a traveller going from a starting point (e.g., home) to one main destination and then returning to the starting point (Lew and McKercher 2002). The Gateway Destination refers to a destination that is the first place the traveller encounters on beginning a multiple destination itinerary. The Gateway is not the main destination, but what is most important is that it is the first place encountered, and therefore it is a liminal point of transition. The Egress Destination is the last destination the tourist visits before travelling home at the end of a multiple destination tour itinerary. The Egress Destination could represent closure and preparation to re-enter the home place after the holiday (Lew and McKercher 2002). When a destination is located after the first stopover place and before the last stopover point, it is a Touring Destination (Lew and McKercher 2002). This only happens on multiple destination trips with three or more overnight stopovers. The Hub Destination is a destination that serves as a transit point. Nevertheless, from an overnight destination perspective, for which the physical transportation route is largely irrelevant, any place that is visited more than once in a multiple destination itinerary can be considered a Hub Destination. Gateway, Egress and Touring Destinations can also be Hub Destinations (Lew and McKercher 2002).

Lew and McKercher (2002) also state that key concepts in tourism are travel itineraries, travel gateways and transportation hubs:

"A travel itinerary consists of a route with one or more stops that a traveler takes. A travel gateway is a place that provides access to (and often travel services for) a destination place or region. A transportation hub is a place where more than one route for a transport medium (usually air or rail) converge and emanate" (Lew and McKercher 2002, 609). 
ToSEE - Tourism in Southern and Eastern Europe, Vol. 6, pp. 709-723, 2021.

A. Sörensson, U. Schmudde: THE CONCEPT OF SHADOW DESTINATION \& VALUE CREATION

The traditional models that have been developed have primarily focused on the flow of travellers from one destination to another (Leiper 1989; Pearce, 1987; Matley 1976) and on variations in the overall pattern of itineraries (Gunn 1997; Oppermann 1995; Mings and McHugh 1992).

Komppula (2016) argues that stakeholders at the destination play a key role. Previous studies have shown that there may exist stakeholders that are the most important in the destination. The stakeholders are often divided into tourism groups such as hotels, restaurants and attractions (Presenza and Cipollina 2010). Some studies have identified primary stakeholders (Komppula 2016), but the role of destination marketing organizations (DMOs) is to synchronize the stakeholders within the destination to work collaboratively towards a more common strategy for the destination (Bregoli and Del Chiappa 2013). It is often these DMOs that have the greatest impact on the stakeholders and lead the destination development (Komppula 2016).

Tourists who visit attractions might also want to experience other things in the nearby area. Tourists often see a destination as one unit, although it is a complex network that involves numerous actors (Haugland et al. 2011). A destination can also be hard to determine geographically. Where does a destination start and finish, particularly in the mind of the tourist? The importance of treating the destination as a unit has resulted in a large amount of research focusing on issues related to destination development (Haugland et al. 2011). Destinations that are situated geographically near to a famous destination could benefit from the strong brand of the well-known destination and use this to increase the numbers of tourists visiting them. Ashton $(2014,279)$ argues that "brand is considered as a powerful instrument in creating a successful destination". Destinations with strong brands have a clear identity as well as a clear image. Tourists feel recognition and, therefore, experience a feeling of familiarity. Shadow destinations could, therefore, create relationships with famous destinations close to their area and benefit from their branding. Research has shown that one way of "moving" tourists beyond a specific tourist attraction to its surrounding areas is to develop different tourist routes: for example, wine routes, scenic routes, or gastronomy routes (Sims 2009). Gastronomy is of great importance to many tourists and is something that can convince tourists to take a detour to experience local cuisine while enjoying the scenery of the region and the destination. As previous mentioned, research has not yet to any great extent addressed the issue of destinations that are situated in the shadow of a wellestablished destination.

\subsection{Value Creation of Shadow Destinations}

Early customer value research focused on how customers value products, such as cars or consumer goods (Vargo and Lusch 2004; Sheth et al. 1991), or services, such as tourism and shadow destinations (Zeithaml et al. 2020). In recent years, researchers and practitioners have moved away from this dyadic perspective on customer value by exploiting the complementary roles of product and service elements. Firms that once focused solely on their product offering now increasingly depend on bundling products and services to secure competitive advantage and, conversely, those that once limited themselves to services now also offer bundled products (Mittal et al. 1999). Researchers 
ToSEE - Tourism in Southern and Eastern Europe, Vol. 6, pp. 709-723, 2021.

A. Sörensson, U. Schmudde: THE CONCEPT OF SHADOW DESTINATION \& VALUE CREATION

and practitioners agree that value is a central concept of the discipline of business administration, as indicated in the American Marketing Association's definition of marketing as "the activity, set of institutions, and processes for creating, communicating, delivering, and exchanging offerings that have value for customers, clients, partners, and society at large" (AMA 2017). Value, in general, is a "customer's perceived preference for, and evaluation of, those product attributes, attribute performances, and consequences that arise from use and that facilitate, or block, the customers in achieving their goals and purposes in use" (Woodruff 1997, 142). Vargo and Lusch (2004) argue that value creation is concerned with offering a service; even when it seems to apply to goods, it is still a service. The proposal for a service-dominant logic means that value arises in the use of a service. It follows from this that the user is a co-creator of value. Thus, value does not arise in production. Through this mindset, everything becomes a service: whether it is goods or (classic) services that are exchanged, the value eventually becomes a service by means of the user who realizes the mediated offer. Every interchange with a customer is important and should have value as the major goal (Osterwalder et al. 2014).

Within the tourism industry, as well as at shadow destinations, the concept of value creation has gained acceptance and is often used in addressing issues such as what value is for the customer and what constitutes value co-creation. Whittington et al. (2020) claim that if value should be seen as a business model for tourism firms, there are three areas that cooperate: (1) value creation, (2) value configuration and (3) value capture. These concepts are explained further below.

\section{Value Creation}

Value creation is the value which firms (tourism actors) create during the buying process in order to be recognized and committed to by their customers (tourists). The concept can be explained by various processes whose purpose is to create value for stakeholders as well as for the tourists. Every interchange with the customer must have value as the priority (Osterwalder et al. 2014). It is crucial to be aware of what services will no longer be of interest to the customers tomorrow. This occurs, for instance, when new competitors enter the market. As a firm, it is important to put great effort into the buying and implementation process, which leads to the highest value creation and is termed as being "customer-centric" (Eletxigerra et al. 2018). Lepak et al. (2007) argue that stakeholders stand to gain from value creation to varying degrees. It is also important to distinguish between value creation and the exchange of value creation. A value is created from the relationship between need and demand, and how well this is satisfied by the destination. The exchange, on the other hand, is the monetary transaction that the firm should aim to provide facilitates (Lepak et al. 2007).

\section{Value Configuration}

The value configuration of firms is concerned with the question, "What does a firm concretely offer to its customers?", and to answer this question it has to be clarified how to operate and deliver value (e g products and services). Making this clarification leads to the understanding that value configuration is a collaboration between various firms to ensure key competencies in order to achieve higher values and competitive advantage (Fjeldstad and Ketels 2006); for example, in the context of a shadow destination, it is 
ToSEE - Tourism in Southern and Eastern Europe, Vol. 6, pp. 709-723, 2021.

A. Sörensson, U. Schmudde: THE CONCEPT OF SHADOW DESTINATION \& VALUE CREATION

important for the destination to be better recognized by its customers. In general, the concept of value proposition holds that products (including goods and services) and experiences lead to value (Kotler and Armstrong 2010). In this study, this means that more attention is directed to the shadow destination in connection to the benefits and experiences that this destination creates (value creation).

\section{Value Capture}

Value capture as a concept is often encountered in discussions about management and organizational issues. The term is used to explain both the microenvironment (near to and around a person and their group) and - partly - the macroenvironment (in modern organizations and in the application of their strategies). The process resulting from value capture is based on value creation and the idea that value comes from resources (Lepak et al. 2007; Bowman and Ambrosini 2000). Simply put, it is the result of the "what" and "how" questions, which means it describes the benefits of value creation, as a final step in the process. Depending on the source of value creation, as well as the degree of competitiveness and isolating mechanisms that exist, the process will create a varying amount of value (Lepak et al. 2007). Bowman and Ambrosini (2000) address an important difference between "creating value" and "capturing value": "resources may be capable of producing profits, but if the resource owner, not the firm, is able to capture this exchange value, firm profitability will suffer" (Bowman and Ambrosini 2000, 8).

In value capture, two major directions have to be differentiated. The first is that of proprofit firms (e.g., Hart 1989), whereby the focus is on reducing the cost of short-term contracts in the marketplace for the sake of value capture or because appropriation is the ultimate goal (Agafonow 2015; James et al. 2013). A second and newer direction is that of the anti-profit firm, which describes a firm that delivers back benefits and services to the local people or society (Bhattacharjee et al. 2017), whereby monetary maximization is not the first priority; instead, customer loyalty and positive word-of-mouth are prioritized (Aaker 2010). Before value capture takes place, value must be created, which requires complex forecasting of future demand and investing capital to fuel a production process that results in outputs (Agafonow 2015; James et al. 2012). Nevertheless, these outputs must pass the test of marketability before rendering any profit.

\section{METHODOLOGY}

The study was constructed as a qualitative multiple-case study, with an abductive approach (Järvensivu and Törnroos 2010). There are several reasons why this study was designed as a case study. Case studies can be seen as a specific research strategy (Eisenhardt 1989; Yin 1989; Halinen and Törnroos 2005). As a social scientist, Yin $(1989,23)$ defines a case study as "an empirical inquiry that investigates a contemporary phenomenon within its real-life context when the boundaries between phenomenon and context are not clearly evident and in which multiple sources of evidence are used" (Halinen and Törnroos 2005, 1286). Yin (1989) also highlights the use of both singleand multiple-case studies. In this study, a multiple-case study was selected, since the purpose was to study destinations. 
ToSEE - Tourism in Southern and Eastern Europe, Vol. 6, pp. 709-723, 2021. A. Sörensson, U. Schmudde: THE CONCEPT OF SHADOW DESTINATION \& VALUE CREATION

Previous research has shown that case study methods may be particularly suitable for studies on value (Yin 2009; Werner et al. 2017), when little is known and there is a need to understand the context (Denzin and Lincoln 2005). Halinen and Törnroos $(2005,1286)$ also argue that:

"the underlying idea for case research is said to be the many-sided view it can provide of a situation in its context". "The intense observation made in case studies gives opportunities to study different aspects and put these in relation to each other, to put objects in relation to the environment where they operate and use the abilities of Verstehen of the researcher" (Valdelin 1974).

Instead of statistical representativeness, case studies offer depth and comprehensiveness for understanding the specific phenomenon (Easton 1995, 475). Case studies provide the opportunity to be close to the studied objects (in this study, the destination), enabling inductive and rich description (Halinen and Törnroos 2005). The case study is also a strong research method because it can focus on contextual factors and process elements. Halinen and Törnroos (2005) identify four important factors in using case studies for researchers of the network, or in this study, the destination (Easton 1995): (1) Problem of network boundaries (what is perceived as the destination), (2) Problem of complexity, (3) Problem of time and (4) Problem of case comparisons.

Five different cases (i.e., shadow destinations) in Sweden were selected based on stratified selection. Sweden was divided into five regions, and one destination from each region was identified (see Figure 1).

Figure 1: The Five Selected Cases, i.e., Destinations (source: own creation)

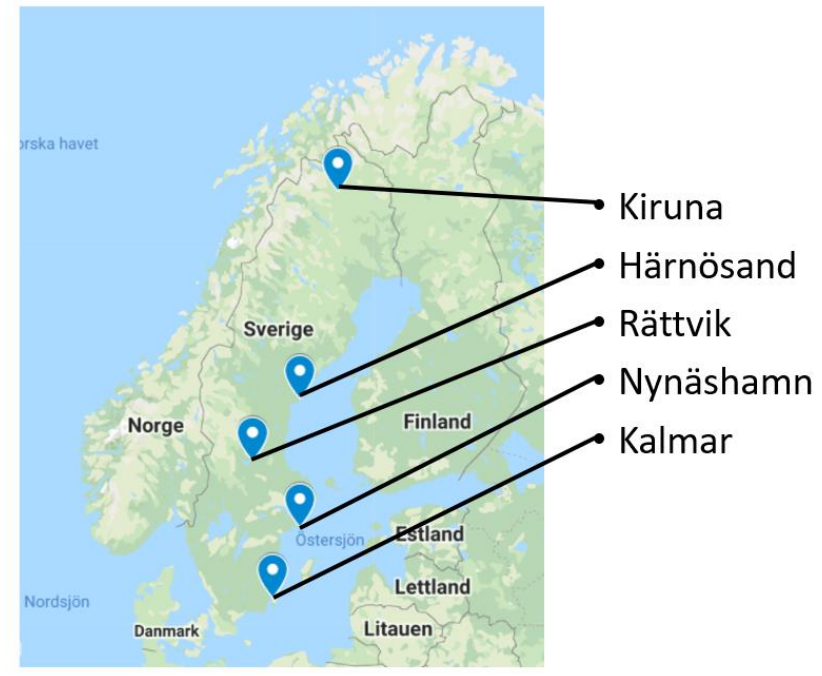

Table 1 illustrates the size of each selected case in terms of guest nights as well as inhabitants. 
ToSEE - Tourism in Southern and Eastern Europe, Vol. 6, pp. 709-723, 2021. A. Sörensson, U. Schmudde: THE CONCEPT OF SHADOW DESTINATION \& VALUE CREATION

Tables 1: The Cases - Shadow Destinations in Sweden

\begin{tabular}{cccc}
\hline $\begin{array}{c}\text { Shadow destination in } \\
\text { Sweden }\end{array}$ & $\begin{array}{c}\text { Region (County) in } \\
\text { Sweden }\end{array}$ & $\begin{array}{c}\text { Guest nights in } \\
\text { the region }\end{array}$ & $\begin{array}{c}\text { Inhabitants in the } \\
\text { destination }\end{array}$ \\
\hline Kiruna & Norrbotten & $1,740,818$ & 22,906 \\
Härnösand & Västernorrland & $1,005,520$ & 17,556 \\
Rättvik & Dalarna & $4,081,810$ & 4,686 \\
Nynäshamn & Stockholm & $6,901,901$ & 13,510 \\
Kalmar & Kalmar & $2,316,624$ & 36,392 \\
\hline
\end{tabular}

Source: SCB, 2020.

Data were collected through interviews, observations and written materials during 20192020. The interviews were conducted using a semi-structured guide, in order to ensure the free expression of the interviewees.

Data were mainly collected from semi-structured interviews with representatives from local municipalities, DMOs, tourism companies and infrastructure companies. A total of 14 respondents were interviewed, and in some cases two interviews were conducted with the same representative.

The interview guide consisted of the following themes: the relationship between different parts of the region or destination (e.g., shadow destination and main attraction) (Haugland et al. 2011), impact on the brand across the different parts of the region (Aaker 2010), cooperation between different stakeholders (Haugland et al. 2011), value creation between different stakeholders (Vargo and Lusch 2004) and tourist information and cooperation in the region (Haugland et al. 2011).

Data from statistics from 2020 were not used, since the COVID-19 pandemic significantly influenced the data; some countries have had travel bans and lockdowns, which made the resulting data unrepresentative. Therefore, 2019 data were used.

The data were then categorized and analysed based on first-order themes and secondorder themes, which led to identification of the dimensions presented in the findings (Gioia et al. 2013; Gioia 2021). We started by taking notes during the interviews, which revealed some of the main findings. After all interviews were conducted, transcripts were printed and we read and highlighted first-order themes and second-order themes. The dataset consisted of more information and themes than are presented in this paper.

\section{FINDINGS}

This chapter is structured to first describe and discuss the concept of shadow destination in relation to the studied cases. Furthermore, shadow destinations and how they cooperate to the main attraction to create value is discussed. 
ToSEE - Tourism in Southern and Eastern Europe, Vol. 6, pp. 709-723, 2021.

A. Sörensson, U. Schmudde: THE CONCEPT OF SHADOW DESTINATION \& VALUE CREATION

\subsection{Shadow Destinations}

The case studies of these five destinations in Sweden identified different types of main attractions that are situated in the vicinity of each shadow destination. Previous research has shown that shadow destinations exist but that there are different types of them (Schmudde and Sörensson 2019). One common dimension that this study has shown is that there seems to exist a geographical reason for this variety of types. Each shadow destination is in the vicinity of - and therefore dependent for different reasons on - the main attraction. As shown in Table 2, the main attraction is identified as well as the key value for the shadow destination.

Table 2: Shadow Destinations and Value Creation

\begin{tabular}{|c|c|c|c|}
\hline $\begin{array}{c}\text { Shadow } \\
\text { destination }\end{array}$ & Main attraction & Main segment & Key value \\
\hline Kiruna & $\begin{array}{l}\text { The Icehotel in } \\
\text { Jukkasjärvi }\end{array}$ & $\begin{array}{l}\text { International tourists } \\
\text { (aeroplane) } \\
\text { Camper tourists (national } \\
\text { and international) }\end{array}$ & $\begin{array}{l}\text { Gateway destination } \\
\text { (airport) } \\
\text { Sami culture } \\
\text { Abisko National Park }\end{array}$ \\
\hline Härnösand & High Coast & $\begin{array}{c}\text { International camper } \\
\text { tourists } \\
\text { National tourists }\end{array}$ & $\begin{array}{l}\text { By the main road } \\
\text { Museums }\end{array}$ \\
\hline Rättvik & $\begin{array}{l}\text { The villages of } \\
\text { Mora and Falun }\end{array}$ & $\begin{array}{c}\text { International camper } \\
\text { tourists } \\
\text { National tourists }\end{array}$ & $\begin{array}{l}\text { Touring Destination (by } \\
\text { the Siljan Lake and part of } \\
\text { Dalarna) }\end{array}$ \\
\hline Nynäs-hamn & $\begin{array}{l}\text { The island of } \\
\text { Gotland }\end{array}$ & $\begin{array}{c}\text { National tourists } \\
\text { Second home owners on } \\
\text { Gotland }\end{array}$ & $\begin{array}{l}\text { Gateway destination } \\
\text { (ferry) }\end{array}$ \\
\hline Kalmar & $\begin{array}{l}\text { The island of } \\
\text { Öland }\end{array}$ & $\begin{array}{c}\text { National tourists } \\
\text { International camper } \\
\text { tourists ( } 11 \% \text { from } \\
\text { Germany, Denmark, } \\
\text { Norway \& Netherlands }{ }^{1} \text { ) }\end{array}$ & $\begin{array}{c}\text { Hub destination } \\
\text { (bridge to Öland and } \\
\text { roads towards different } \\
\text { parts of Sweden) }\end{array}$ \\
\hline
\end{tabular}

The tourists who travel to Kiruna come from both national and international segments. The international tourists who travel to Kiruna by aeroplane see the destination as a transit destination: they fly to Kiruna, and then they are transported to the main attraction, which, during wintertime, is the Icehotel. The other segment represented is tourists who come by car or camper, who are more mobile and travel around to a greater extent within the region. Many tourists also travel during the summer to Abisko National Park. These tourists are both national and international. In 2019, the number of guest nights increased by $8.3 \%$ in the Kiruna area, which corresponds to 484,000 guest nights, according to the latest statistics from Statistics Sweden. To this must be added 65,000 guest nights from AirBnB, which in total means that 2019 was a record year for the Kiruna area. The

${ }^{1}$ https://www.pressmachine.se/pressrelease/view/rekordmanga-utlandska-gaster-pa-oland-2019-17450, accessed 2021-05-16 
ToSEE - Tourism in Southern and Eastern Europe, Vol. 6, pp. 709-723, 2021. A. Sörensson, U. Schmudde: THE CONCEPT OF SHADOW DESTINATION \& VALUE CREATION

summer season, July and August, is already a strong period, but in 2019 there was also a large increase in the number of guest nights in June, compared to previous years.

Winter is also a strong period that attracts many foreign visitors. The foreign guest nights increased by $15 \%$ (Besöksliv 2020).

Härnösand is a residential city in the county of Västernorrland. Many tourists travel to the UNESCO archipelago High Coast, which starts geographically $25 \mathrm{~km}$ north of Härnösand. Since it is the residential city, several of the county's museums are situated in Härnösand.

Rättvik is situated around the lake of Siljan. Many of the tourists travel around the lake which is a travel route. The DMO is for the region of Dalarna, of which Rättvik is part. Dalarna is the largest tourism destination in Sweden, with around 15.5 million guest nights in 2019 (the total for Sweden as a whole being slightly more than 67 million guest nights), $86 \%$ of which were national tourists and $14 \%$ international tourists (Visit Dalarna 2019).

A common feature is what Nynäshamn and Kalmar experience. They are both smaller cities which operate as the port and bridge to another, larger summer destination in Sweden. Sweden's largest island, Gotland, is a sizeable summer destination in which many people have summer houses as well as spending their holidays there. The main segment group is national tourists, although there are also international tourists. Nynäshamn's situation is similar to that of Kalmar, which is the city in which the bridge to the second largest island in Sweden, Öland, is situated. Öland is quite similar to Gotland in some ways: they are both large summer destinations in Sweden. Kalmar is more of a hub destination, since it also has several roads that connect Kalmar to other parts of Sweden. Both Kalmar and Öland are situated on the southern part of Sweden's east coast. In 2019, the county of Kalmar had around three million guest nights. In total, there were almost 2.2 million so-called commercial overnight stays during the summer months (JuneAugust). This places Kalmar County in an unthreatened fourth place after Stockholm, Västra Götaland and Skåne (Region Kalmar Län 2019). Around one million tourists travelled by ferry to Gotland from Nynäshamn during 2019 (Destination Gotland 2020). Kalmar was awarded "best summer city" in 2019.

\subsection{Value Creation of Shadow Destinations}

Tourists choose where they travel, and there are many destinations to choose from. What this study has shown is that shadow destinations have their own attractions but are not as popular among tourists, and they do not have brands as strong as those of the well-known destinations. It is therefore important that the shadow destinations cooperate and work together with the main destinations to create greater value for tourists. What does the customer want? What does the customer not know that they want, but which could add value to the overall experience? One result of the study is that there are weak connections between shadow and main destinations, and thus there is a lack of opportunities for shadow destinations to increase their value for tourists. 
ToSEE - Tourism in Southern and Eastern Europe, Vol. 6, pp. 709-723, 2021.

A. Sörensson, U. Schmudde: THE CONCEPT OF SHADOW DESTINATION \& VALUE CREATION

A clear example from the study is the shadow destination Rättvik, which is more clearly part of a whole, as tourists follow a route around the Lake of Siljan. This means that they indirectly pass the towns along the road, and the shadow destination has the opportunity to offer value to these tourists.

Value configuration is about how value is created at shadow destinations for tourists. This study may suggest how to create a strong collaboration between the shadow destination and the established destination. In this study, the focus was not particularly on value configuration, and thus more data collection would be useful.

Value capture is what the company has to gain from value creation. For shadow destinations, there may be an increased number of tourists, with increased revenue as a result. It can also be possible to strengthen the brand. This can be done by being part of a larger whole (the destination is broadened to include both the well-known destination and the shadow destination). In this study, the results show that tourists pass by, and the shadow destinations that are good at offering their own value to the tourists also secure an increased tourist flow. This also leads to the tourists being able to experience an increased value.

A significant benefit is that tourists are spread out in the region; above all, this is good from a sustainability perspective. By encouraging tourists to broaden their view of the destination and add to it by visiting the shadow destination, an exchange takes place. This leads to reduced pressure on the established destination, which is more sustainable. This, in turn, leads to increased value for the tourist. Figure 2 illustrates the flow of value between the destinations.

Figure 2: Flow of Value (source: own creation)

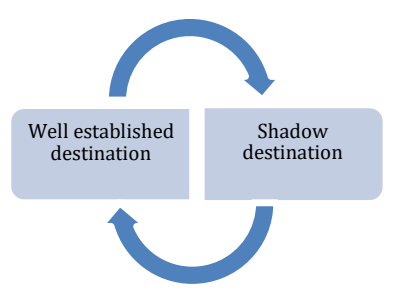

\section{CONCLUSION}

The purpose of this paper was to gain a deeper understanding of the concept of shadow destinations. The conclusion from this study is that each of the studied cases has different ties to the main attraction in the region. This study's theoretical contribution demonstrates that the concept of shadow destinations has not been addressed to any significant extent in tourism research; the concept requires further studies. This study 
ToSEE - Tourism in Southern and Eastern Europe, Vol. 6, pp. 709-723, 2021.

A. Sörensson, U. Schmudde: THE CONCEPT OF SHADOW DESTINATION \& VALUE CREATION

offers a contribution to tourism development of destinations. Most of the studied cases are gateway destinations: tourists come to the shadow destination due to travel reasons (Nynäshamn as the port, Kalmar as the gate to the bridge to Öland, Kiruna for its airport and Härnösand because it situated by the travel route along the main road). Rättvik, however, is a touring destination, as it is part of the route around the lake of Siljan.

It can be concluded from this study that shadow destinations are highly dependent on some sort of main attraction in the region. The results also show that there exist different types of shadow destinations, and that shadow destinations can create value for the tourists in order to become more important for tourism in the region, as well as in order to become main destinations by themselves.

One conclusion the study draws is that shadow destinations exist and are a form of destination that has not yet been researched to any great extent. The concept of the shadow destination has no negative or illegal connotations (as, for example, do shadow economies). Rather, central to the concept of the shadow destination is its relationship to another, more well-known destination. More research should be undertaken both on the concept and what it includes, but the relationship between shadow destinations and wellestablished destinations also needs to be studied in more depth.

A theoretical contribution from the study is that Lew and McKercher's (2002) categorization of five different types of destinations needs to include perspectives on shadow destinations. Shadow destinations exist and are a new theoretical concept to describe and analyse destinations and their development. The relationship between the established destination and the shadow destination is interesting from a value-creating perspective.

Practical implications from this study are that shadow destination should cooperate with established destinations. By expanding a destination, tourists can be spread over a larger area, which should lead to a more sustainable tourism development. More research is needed on shadow destinations from different perspectives, such as cooperation, value creation and ways to lead tourists in the area for more sustainable tourism development. This is a small initial study in the field of shadow destinations around which it is not possible to draw major conclusions. More extensive studies are needed to draw some farreaching conclusions.

Previous research on value creation has mostly been concerned with how destinations create value for tourists or other types of stakeholders. The contribution of this study is instead to consider what the relationship looks like between the well-established destination and the shadow destination. With a perspective on value creation, both destinations can contribute to increased value for the visiting tourist. This can take the form of a value added to the well-known destination, but it can also be the other way around: the value can be increased at the shadow destination if it is linked to the wellknown one. More extensive research is needed on how these two destinations can be linked to increase value. 
ToSEE - Tourism in Southern and Eastern Europe, Vol. 6, pp. 709-723, 2021.

\section{REFERENCES}

Aaker, D.A. (2010), Building strong brands, Simon \& Schuster UK Ltd., London.

Agafonow, A. (2015), "Value creation, value capture, and value devolution: Where do social enterprises stand?", Administration \& Society, Vol. 47, No. 8, pp. 1038-1060.

AMA, American Marketing Association (2017), Definition of Marketing, available from https://www.ama.org/AboutAMA/Pages/Definition-of-Marketing.aspx, accessed 2021-05-15.

Bhattacharjee, A., Dana, J. and Baron, J. (2017), ”Anti-profit beliefs: How people neglect the societal benefits of profit", Journal of Personality and Social Psychology, Vol. 113, No. 5, pp. 671-696. https://doi.org/10.1037/pspa0000093

Beritelli, P. and Bieger, T. (2014), "From destination governance to destination leadership - defining and exploring the significance with the help of a systemic perspective", Tourism Review, Vol. 69, No. 1 , pp. $25-46$.

Besöksliv (2020), https://www.besoksliv.se/nyheter/rekord-for-kirunas-besoksnaring/, accessed 2021-05-15.

Bowman, C. and Ambrosini, V. (2000), "Value Creation Versus Value Capture: Towards a Coherent Definition of Value in Strategy", British Journal of Management, Vol. 11, pp. 1-15. https://doi.org/10.1111/1467-8551.00147

Brambini, A., and Vang, J. (2013), "Policy measures for creating an integrated and brand-focused regional innovation system in tourism in a shadow destination: insights from Pisa's destination development strategy", International Journal of Business and Globalisation, Vol. 10, No. 2, pp. 194-219.

Bregoli, I. and Del Chiappa, G. (2013), "Coordinating relationships among destination stakeholders: evidence from Edinburgh (UK)", Tourism Analysis, Vol. 18, No. 1, pp. 145-155.

Chathoth, P.K., Ungson, G.R., Harrington, R.J. and Chan, E. S. (2016), "Co-creation and higher order customer engagement in hospitality and tourism services", International Journal of Contemporary Hospitality Management, Vol. 28 No. 2, pp. 222-245. https://doi.org/10.1108/IJCHM-10-20140526

Denzin, N.K., and Lincoln, Y.S. (2005), "Introduction: The Discipline and Practice of Qualitative Research", in Denzin, N.K. and Lincoln, Y.S. (Eds.), The Sage handbook of qualitative research, Sage Publications Ltd., pp. 1-32.

Destination Gotland (2020), https://www.destinationgotland.se/sv/om-oss/destination-gotland-ab/statistik/, accessed 2021-05-15

Easton, G. (2003), "Case research as a method for industrial networks: a realist apologia", in Realist perspectives on management and organisations, Routledge, pp. 221-235.

Eisenhardt, K.M. (1989), "Building theories from case study research", Academy of management review, Vol. 14 , No. 4, pp. 532-550

Eletxigerra, A., Barrutia, J.M. and Echebarria, C. (2018), "Place marketing examined through a servicedominant logic lens: A review", Journal of Destination Marketing \& Management, Vol. 9, pp. 7284

Fjeldstad, Ø. D. and Ketels, C.H. (2006), "Competitive advantage and the value network configuration: making decisions at a Swedish life insurance company", Long Range Planning, Vol. 39, No. 2, pp. 109131. https://doi.org/10.1016/j.lrp.2006.05.001

Gioia, D. (2021), "A Systematic Methodology for Doing Qualitative Research", The Journal of Applied Behavioral Science, Vol. 57, No. 1, pp. 20-29. https://doi.org/10.1177/0021886320982715

Gioia, D.A., Corley, K.G., and Hamilton, A.L. (2013), "Seeking qualitative rigor in inductive research: Notes on the Gioia methodology", Organizational research methods, Vol. 16, No. 1, pp. 15-31.

Gunn, C.A. (1997), Vacationscape: Developing tourist areas, Taylor \& Francis.

Halinen, A. and Törnroos, J.Å. (2005), "Using case methods in the study of contemporary business networks", Journal of business research, Vol. 58, No. 9, pp. 1285-1297. https://doi.org/10.1016/j.jbusres.2004.02.001

Haugland, S.A., Ness, H., Grønseth, B.O. and Aarstad, J. (2011), "Development of tourism destinations: An integrated multilevel perspective", Annals of Tourism Research, Vol. 38, No. 1, pp. 268-290. https://doi.org/10.1016/j.annals.2010.08.008

Heo, Y. (2016), "Sharing economy and prospects in tourism research", Annals of Tourism Research, Vol. 58, pp. $166-170$.

Hudman, L. and Jackson, R. (2003), Geography of Travel and Tourism, (4th ed.), Cengage Learning.

Järvensivu, T. and Törnroos, J.A. (2010), "Case study research with moderate constructionism: Conceptualization and practical illustration", Industrial Marketing Management, Vol. 39, No. 1, pp. 100-108. https://doi.org/10.1016/j.indmarman.2008.05.005

James, S.D., Leiblein, M.J. and Lu, S. (2013), "How firms capture value from their innovations", Journal of Management, Vol. 39, No. 5, pp. 1123-1155. 
ToSEE - Tourism in Southern and Eastern Europe, Vol. 6, pp. 709-723, 2021.

Johnson, A.G. and Neuhofer, B. (2017), "Airbnb-an exploration of value co-creation experiences in Jamaica", International Journal of Contemporary Hospitality Management, Vol. 29, No. 9, pp. 23612376. https://doi.org/10.1108/IJCHM-08-2016-0482

Kladou, S., Kavaratzis, M., Rigopoulou, I. and Salonika, E. (2017),” The role of brand elements in destination branding", Journal of Destination Marketing \& Management, Vol. 6, No. 4, pp. 426-435. https://doi.org/10.1016/j.jdmm.2016.06.011

Komppula, R. (2016), "The role of different stakeholders in destination development", Tourism Review, Vol. 71, No. 1, pp. 67-76. https://doi.org/10.1108/TR-06-2015-0030

Kotler, P. and Armstrong, G. (2010), Principles of Marketing, Pearson Education.

Laesser, C. and Beritelli, P. (2013), "St. Gallen consensus on destination management", Journal of Destination Marketing \& Management, Vol. 2, No. 1, pp. 46-49. https://doi.org/10.1016/j.jdmm.2012.11.003

Laws, E. (1995), Tourist destination management: issues, analysis and policies, Routledge.

Leiper, N. (1989), "Main destination ratios: Analyses of tourist flows", Annals of Tourism Research, Vol. 16, No. 4, pp. 530-541. https://doi.org/10.1016/0160-7383(89)90007-8

Lepak, P.D., Smith, G.K. and Taylor, S.M. (2007), "Value Creation and Value Capture: A multilevel perspective", Academy of Management Review, Vol. 32, No. 1, pp. 180-194. https://doi.org/10.5465/amr.2007.23464011

Lew, A.A. and McKercher, B. (2002), "Trip destinations, gateways and itineraries: The example of Hong Kong”, Tourism Management, Vol. 23, No. 6, pp- 609-621. https://doi.org/10.1016/S02615177(02)00026-2

Matley, I.M. (1976), The Geography of International Tourism, Resource Paper No. 76-1.

Mings, R.C., and McHugh, K.E. (1992), "The spatial configuration of travel to Yellowstone National Park", Journal of travel research, Vol. 30, No. 4, pp. 38-46. https://doi.org/10.1177/004728759203000406

Mittal, V., Kumar, P. and Tsiros, M. (1999), "Attribute-level performance, satisfaction, and behavioral intentions over time: a consumption-system approach”, Journal of Marketing, Vol. 63, No. 2, pp. 88-101. https://doi.org/10.1177/002224299906300206

Oppermann, M. (1995), “A model of travel itineraries”, Journal of Travel Research, Vol. 33, No. 4, pp. 5761. https://doi.org/10.1177/004728759503300409

Osterwalder, A., Pigneur, Y., Bernarda, G. and Smith, A. (2015), Value proposition design, Campus Verlag.

Osterwalder, A., Pigneur, Y., Bernarda, G. and Smith, A. (2014), Value proposition design: How to create products and services customers want, John Wiley \& Sons.

Payne, A.F., Storbacka, K., and Frow, P. (2008), "Managing the co-creation of value", Journal of the Academy of Marketing Science, Vol. 36, No. 1, pp. 83-96.

Pearce, D.G. (1987), "Spatial patterns of package tourism in Europe”, Annals of tourism research, Vol. 14, No. 2, pp. 183-201. https://doi.org/10.1016/0160-7383(87)90084-3

Pechlaner, H., Kozak, M. and Volgger, M. (2014), "Destination leadership: a new paradigm for tourist destinations?", Tourism Review, Vol. 69, No. 1, pp. 1-9. https://doi.org/10.1108/TR-09-2013-0053

Pechlaner, H., Raich, F., and Beritelli, P. (2010). Destination governance. Tourism Review, 65(4), 4-85.

Presenza, A. and Cipollina, M. (2010), “Analysing tourism stakeholders networks”, Tourism Review, Vol. 65, No. 4, pp. 17-30. https://doi.org/10.1108/16605371011093845

Region Kalmar Län (2019), https://www.regionkalmar.se/nyhetslista/flest-sommarturister-i-kalmar-lan-efterlandets-storstadsregioner/, accessed 2021-05-16.

Ritchie, J.B. and Crouch, G.I. (2003), The competitive destination: A sustainable tourism perspective, Cabi.

Saarinen, J., Rogerson, C.M. and Hall, C.M. (2017), "Geographies of tourism development and planning", Tourism Geographies, Vol. 19, No. 3, pp. 307-317. https://doi.org/10.1080/14616688.2017.1307442

Saraniemi, S. and Komppula, R. (2019), "The development of a destination brand identity: A story of stakeholder collaboration", Current Issues in Tourism, Vol. 22, No. 9, pp. 1116-1132. https://doi.org/10.1080/13683500.2017.1369496

SCB (2020), https://www.statistikdatabasen.scb.se/pxweb/sv/ssd/, accessed 2021-05-15.

Schmudde, U. and Sörensson, A. (2020), "Tourism Development in Rural Areas in Sweden-In the Shadow of a Well-Established Destination", Athens Journal of Tourism, Vol. 7, No. 1, pp. 55-74. doi: 10.30958/ajt.7-1-4

Shen, Y., Morrison, A.M., Wu, B., Park, J., Li, C. and Li, M. (2018), "Where in the world? A geographic analysis of a decade of research in tourism, hospitality, and leisure journals", Journal of Hospitality \& Tourism Research, Vol. 42, No. 2, pp. 171-200. https://doi.org/10.1177/1096348014563394

Sheth, J.N., Newman, B.I. and Gross, B.L. (1991), "Why We Buy What We Buy: A Theory of Consumption Values," Journal of Business Research, Vol. 22, No. 2, pp. 159-170. https://doi.org/10.1016/0148 2963(91)90050-8

Sims, R. (2009), "Food, place and authenticity: local food and the sustainable tourism experience", Journal of Sustainable Tourism, Vol. 17, No. 3, pp. 321-336. https://doi.org/10.1080/09669580802359293 
ToSEE - Tourism in Southern and Eastern Europe, Vol. 6, pp. 709-723, 2021.

A. Sörensson, U. Schmudde: THE CONCEPT OF SHADOW DESTINATION \& VALUE CREATION

Tinsley, R. and Lynch, P. (2001), "Small tourism business networks and destination development", International Journal of Hospitality Management, Vol. 20, No. 4, pp. 367-378. https://doi.org/10.1016/S0278-4319(01)00024-X

Valdelin, J. (1974), Produktutveckling och marknadsföring — en undersökning av produktutvecklingsprocesser i svenska företag, EFI, Handelshögskolan i Stockholm.

Vargo, S.L. and Lusch, R.F. (2004), Evolving to a new dominant logic for marketing (pp. 21-46), Routledge.

Vargo, S.L. and Lusch, R.F. (2016), "Institutions and axioms: an extension and update of service-dominant logic", Journal of the Academy of marketing Science, Vol. 44, No. 1, pp. 5-23. doi: 10.1007/s11747-015-0456-3

Vargo, S.L., Maglio, P.P. and Akaka, M.A. (2008), "On value and value co-creation: A service systems and service logic perspective”, European management journal, Vol. 26, No. 3, pp. 145-152. https://doi.org/10.1016/j.emj.2008.04.003

Visit Dalarna (2019), https://www.visitdalarna.se/corporate/statistik, accessed 2021-05-15

Volgger, M., Erschbamer, G. and Pechlaner, H. (2021), "Destination design: New perspectives for tourism destination development", Journal of Destination Marketing \& Management, Vol. 19, 100561. https://doi.org/10.1016/j.jdmm.2021.100561

Werner, K., Griese, K.M. and Hogg, J. (2017), "Service dominant logic as a new fundamental framework for analyzing event sustainability: A case study from the German meetings industry", Journal of Convention \& Event Tourism, Vol. 18, No. 4, pp. 318-343. https://doi.org/10.1080/15470148.2017.1365670

Whittington, R., Regnér, P., Angwin, D., Johnson, G. and Scholes, K. (2020), Exploring Strategy Text and Cases, Pearson UK

Woodruff, R.B. (1997), "Customer value: the next source for competitive advantage", Journal of the academy of marketing science, Vol. 25, No. 2, pp. 139-153.

Zeithaml, V.A., Verleye, K., Hatak, I., Koller, M. and Zauner, A. (2020), “Three decades of customer value research: paradigmatic roots and future research avenues", Journal of Service Research, Vol. 23, No. 4, pp. 409-432. https://doi.org/10.1177/1094670520948134

Yin, R.K. (1989), Case study research: Design and methods. Sage, Thousand Oaks, CA

Yin, R.K. (2009), Case study research: Design and methods, Sage, Thousand Oaks, CA.

Anna Sörensson, $\mathrm{PhD}$, Senior lecturer

Mid Sweden University

Department of Economics, Geography, Law and Tourism (EJT)

Kunskapens v 4, 83125, Östersund, Sweden

+46-70-5774202

anna.sorensson@miun.se

Ulrich Schmudde, PhD student, Lecturer

Mid Sweden University

Department of Economics, Geography, Law and Tourism (EJT)

Kunskapens v 4, 83125, Östersund, Sweden

+46-72-5818612

ulrich.schmudde@miun.se 